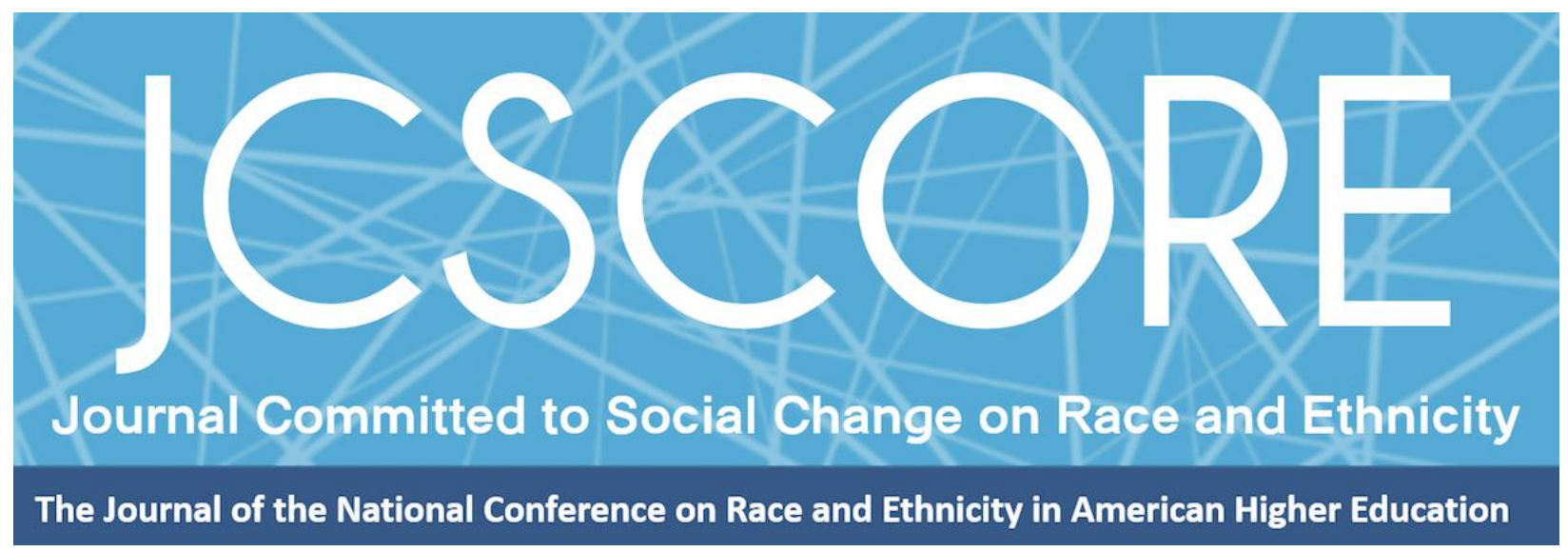

\title{
WHITE HIGHER EDUCATION LEADERS ON THE COMPLEXITIES OF WHITENESS AND ANTI-RACIST LEADERSHIP
}

\author{
Dustin Evatt-Young \\ Oberlin College \& Conservatory \\ Brandy S. Bryson \\ Appalachian State University
}

Journal Committed to Social Change on Race and Ethnicity Volume 7, Issue 1| 2021

\section{Copyright and Open Access}

(C) 2021 Dustin Evatt-Young, Brandy S. Bryson

\section{c) (i) (2)}

This work is licensed under a Creative Commons Attribution-NonCommercial-ShareAlike 4.0 International License. Permission of the authors is required for distribution and for all derivative works, including compilations and translations. Quoting small sections of text is allowed as long as there is appropriate attribution and the article is used for non-commercial purposes.

The Journal Committed to Social Change on Race and Ethnicity (ISSN 2642-2387) is published by the National Conference on Race and Ethnicity (NCORE), a production of the University of Oklahoma, in partnership with the University of Oklahoma Libraries. 


\title{
White Higher Education Leaders on the Complexities of Whiteness and Anti-Racist Leadership
}

\author{
Dustin Evatt-Young \\ Oberlin College \& Conservatory \\ Brandy S. Bryson \\ Appalachian State University
}

\begin{abstract}
In the midst of a global pandemic, racialized violence, and civil unrest, higher education leaders are faced with a difficult reality as their constituents call for meaningful engagement and leadership. While many higher education institutions claim to value racial equity and inclusion and have identified them as hallmarks in their mission statements or strategic plans, a culture of whiteness and everyday white supremacy continue to plague higher education institutions. Given the limited research that examines White higher education leaders' perspectives on race, racism and anti-racist leadership efforts, this critical phenomenological study explores how ten White higher education leaders navigate racial equity efforts at their institutions and the role their racial identity plays in the process. Specifically, this study examines the complexities and intricacies of whiteness in higher education and offers insight into the development of anti-racist policies, practices, and tools for White higher education leaders to begin thinking about their work in relation to their whiteness.
\end{abstract}

As we ${ }^{1}$ have witnessed throughout history, and more acutely in 2020 , an urgent call withstands for higher education leaders to transform our systems, structures, and approaches for moving our institutions forward. In the midst of a global pandemic, racialized violence, and civil unrest in the United States and globally, higher education leaders are faced with a difficult reality as students, faculty, staff, and alumni call for their engagement and leadership. As the realities of racism have intensified, many

\footnotetext{
${ }^{1}$ Throughout this article, we use the words "our" and "we" to indicate that we are also part of the white racial majority, thus positioning ourselves directly in this work. In doing so, our intention is not to exclude but rather to put the focus on White leaders who should be doing the heavy lifting in the pursuit of racial equity in higher education.
} 
Journal Committed to Social Change on Race and Ethnicity | Volume 7, Issue 1 | 2021

leaders have felt moved to release statements of commitment to racial justice and equity, while other leaders grapple with the pressure to make such statements during uncertainty and political polarization. This racial tension highlights scholars' cautions about the difference between claiming racial equity and being racially equitable (Ahmed, 2005). Struggling to respond, many leaders rely on traditional forms of leadership to conduct "business as usual" in hopes to project normalcy and stability to their constituencies. Consequently, this approach serves to replicate the existing racial paradigm of white supremacy in higher education (Gusa, 2010). Many institutions fall short in their pursuit of racial equity because they do not critically examine how whiteness manifests in daily practice. In order to make transformative change, higher education leaders must address underlying systems and structures that, intentionally or not, maintain racism and racial inequity.

In his work, Nolan Cabrera (2017) focuses on white privilege as a strategy for change, and calls on educators to respond to the systemic reality of contemporary white supremacy. He urges educators to understand and describe the "nature of this systemic reality while centering the human suffering it causes People of Color" while simultaneously "link[ing] this reality to White responsibility, and highlight[ing] how inaction only serves to reify contemporary White supremacy" (Cabrera, 2017, p. 87). In this article, we respond to Cabrera's (2017) call by examining White higher education leaders' engagement in working against white supremacy and whiteness. Our intention is not to flourish more empirical racial navel gazing (Cabrera, 2017) or white narcissism (Matias, 2016), but instead to highlight actions to help White leaders dismantle systems of white supremacy, starting from a place of their own experiential understanding. Given 
Journal Committed to Social Change on Race and Ethnicity | Volume 7, Issue 1 | 2021

the fact that White people hold the overwhelming majority of leadership positions in U.S. higher education (Bichsel \& McChesney, 2017), White leaders must dig beneath the normalcy and embeddedness of racism in our institutions, organizations, cultural values, and daily interactions (Delgado \& Stefancic, 2001). This begins with situating leaders' understanding of leadership in the racial privileges, realities, and complexities of whiteness and everyday white supremacy.

The intellectual goal of this study was to unmask the dominant ideology that sustains whiteness in higher education, while the practical goal was to support White leaders in developing anti-racist leadership practices. This study on whiteness and leadership is both timely and critical to higher education, as we continue to witness daily acts of racism and white supremacy in our society and within our institutions. This work is relevant to White leaders' knowledge about the phenomenon of whiteness - the root problem being protested nationally by Students of Color and Black Lives Matter and allied activist groups. The implications of this research are particularly important for White leaders working in higher education at all levels of the institution - administrators, faculty, staff, trustees, among other leaders - because White leaders hold power, both racial and positional, to make decisions about the institution's future including climate, curriculum, finances, human resources, facilities, and co-curricular activities (Chesler et al., 2005).

Therefore, the purpose of this critical phenomenological study was to explore how White higher education leaders navigate racial equity and inclusion efforts at their institutions and the role their racial identity plays in the process. To accomplish the purpose of this study, the following research questions guided our inquiry: (1) How do 
Journal Committed to Social Change on Race and Ethnicity | Volume 7, Issue 1 | 2021

White higher education leaders who claim to do racial justice work navigate racial equity and inclusion efforts at their institution? and (2) In what ways do these leaders' approaches to racial equity and inclusion efforts offer insight into the development of institutional anti-racist policies and practices?

\section{Theoretical Framework ${ }^{2}$}

Critical Whiteness Studies (CWS) framed this research. The purpose of CWS is to reveal the frequently invisible social structures and systems that continually recreate white supremacy and white privilege. Stemming from Critical Race Theory, CWS theorizes whiteness as a system existing within a social, political, historical, and economic context. The focus is on sociocultural structures along with individuals and their identities. CWS challenges dominant ideology and critically examines how the unmeritocratic and unwarranted privileges of whiteness are both enacted, normalized, and maintained within society and its institutions. It is not merely the study of white privilege, but the study of white supremacy and whiteness given that it is "the condition of white supremacy that makes white privilege possible" (Leonardo, 2004, p. 137). We refer to white supremacy as the "political, economic, and cultural system in which White [people] overwhelmingly control power and material resources" (Ansley, 1997, p. 592). This type of everyday white supremacy is reenacted daily and is framed as "normal." This hidden norm is frequently recreated as socially acceptable within the context of higher education and is central to the continuation of the racialized status quo (Cabrera, 2012; Feagin et al., 1996; Gusa, 2010). Furthermore, racial ideologies are always

\footnotetext{
${ }^{2}$ We place the theoretical framework before the literature review as the framework defines the concepts we discuss in the literature review and provides a connection between the introduction and literature review section.
} 
Journal Committed to Social Change on Race and Ethnicity | Volume 7, Issue 1 | 2021

produced and rearticulated in relation to whiteness (Bonilla-Silva, 2001, 2006). Thus, the degree to which racialized experiences are transparent to White people is vital to understanding the nuances of how race and privilege play out in higher education. To move beyond awareness, it is necessary to understand racism as systemic and make the invisible visible by highlighting the ways in which society structures and recreates whiteness (Ortiz \& Rhoads, 2000).

\section{Whiteness in Higher Education}

The reality of whiteness and everyday white supremacy plague our individual consciousness and social institutions. As Patton (2016) argues, higher education itself was born out of white supremacy and "is intricately linked to imperialistic and capitalistic efforts that fuel the intersections of race, property, and oppression" (p. 317). This acculturation into whiteness continues to permeate campus cultures and climates of U.S. higher education institutions (Bryson, 2017; Harper \& Hurtado, 2007; Milem et al., 2005). The overwhelming presence of White cultural norms and White people centers whiteness as the dominant cultural norm, particularly at predominantly white institutions (Gusa, 2010; Harper \& Hurtado, 2007). This dominant culture and climate of whiteness is further contextualized in the development of individual identities on college campuses (Hurtado et al., 2012). One method of whiteness normalization is the disparate representation of White people in higher education, especially at four-year institutions (Brown, 2004). According to Bichsel and McChesney (2017), only 7\% of higher education leadership positions (e.g. top executive administrators like controllers, division heads, department heads, deans and associate deans) were held by Black 
Journal Committed to Social Change on Race and Ethnicity | Volume 7, Issue 1 | 2021

administrators; $3 \%$ were held by Latin $x^{3}$ people; $2 \%$ were Asian; and $1 \%$ identified as another race or ethnicity while the remaining $86 \%$ of administrators were White. Patton (2016) further describes these White norms as "cloaked in the myth of hard work" ( $p$. 327 ) as "higher education as an entity has been complicit in submitting to the ideals of colorblindness and race neutrality" (Patton et al., 2015, p. 196).

The reification of this overwhelming presence of whiteness manifests through myriad white-normed hiring processes and practices. Academic searches often use the notion of "good fit" to judge applicants' candidacy despite research clearly indicating the notion of "good fit" in candidate selection is both racially coded and problematic (Liera \& Ching, 2020; Tuitt et al., 2007; White-Lewis, 2020). "Good fit" has a cloning effect and tends to reaffirm homogenous departments, divisions, and institutions (Wade-Golden \& Williams, 2013; Williams, 2013). In a qualitative study with 23 academic personnel participants including deans, department chairs, equity administrators, and search committee members, White-Lewis (2021) examined hiring priorities and the underlying mechanics of academic hiring that support or avert diversity. The author found that search committees and hiring authorities created determinants for diverse hires through their hesitancy to expand academic departments in new and innovative ways, thus inhibiting the ability to attract and elevate racially minoritized candidates before active searches even began. The notion of "good fit," White-Lewis (2020) asserts, is "code for determining if candidates had the appropriate cultural capital, including language, presentation, and style of social interaction that were palatable to predominantly white search committees" (p. 2).

\footnotetext{
${ }^{3}$ We use Salinas and Lozano's (2019) work to define Latinx as "an inclusive term that recognizes the intersectionality of sexuality, language, immigration, ethnicity, culture, and phenotype" (p. 310).
} 
Journal Committed to Social Change on Race and Ethnicity | Volume 7, Issue 1 | 2021

While truly inclusive forms of representation are necessary for equitable environments and student success, at the same time, proportional representation is only part of the problematic landscape of whiteness. Additional issues that perpetuate whiteness include an institutional stance on racism that is reactive instead of proactive (Welton et al., 2018; Williams, 2013), racial justice as rhetoric (Patton, 2016; Stewart, 2018; Welton et al., 2018), the exclusion of diversity, equity, and inclusion in mission statements and strategic plans (Wade-Golden \& Williams, 2013), the denial or deflection of racist acts on campus as isolated incidents in order to protect the institution's public image (Harper, 2020) or incidents of ignorance (Dancy et al., 2018), commodification and marketization of bodies of Color for statistical proof and accreditation points (Matias, 2015; Squire et al., 2018), and a reliance upon methods that perpetuate underrepresentation in the curriculum and ineffective teaching across racial difference (Bryson et al., 2020; Matias \& Grosland, 2016; Patton, 2016; Welton et al., 2018). These and other manifestations of whiteness are layered and complex.

The research on whiteness in higher education also points to whiteness as niceness. Whiteness as niceness perpetuates white cultural norms and diverts attention from the realities of structural and cultural racism. For example, Liera (2020a) examined how a culture of niceness is perpetuated through academic hiring given that hiring "is a racialized structure because of racial meanings of who is worthy of being hired guide hiring routines" (p. 1955). Thus, hiring committees maintain a culture of niceness when they use race-neutral language to explain the existence of racial inequity (Dowd \& Bensimon, 2015) and exonerate themselves from any responsibility to advance racial equity (Harper \& Patton, 2007). Studying how White male faculty and administrators 
Journal Committed to Social Change on Race and Ethnicity | Volume 7, Issue 1 | 2021

construct ally work in higher education, Patton and Bondi (2015) found that it is common for White administrators, particularly White men, to reify the whiteness as niceness culture that permeates higher education. Furthermore, White male administrators often receive praise for racial justice efforts without taking risks or making sacrifices (Patton \& Bondi, 2015). Thus, it appears that the work in which participants engaged is more reflective of "nice guy" activities that do not necessarily challenge the status quo, thus perpetuating a culture of niceness rather than addressing structural racism.

Whiteness "is visible most clearly to those it definitely excludes... those who are securely housed within its borders usually do not examine it" (Frankenberg, 1993, p. 228-229). Therefore, the invisibility of whiteness makes it difficult for White higher education leaders to acknowledge and understand their racial privilege (Cabrera, 2009) and racial "blindspots" despite claiming to create racially inclusive environments. Kezar and Posselt (2020) connect this invisibility and blindspots to important power dynamics:

Without administrators being constantly vigilant about power, its misuse, and the interlocking systems of power associated with identities and social statuses, unequal power dynamics (i.e. power asymmetries) are likely to be present, either on purpose (i.e. directly) or as the result of a blindspot (i.e. indirectly). (p. 11)

Ignoring race maintains the status quo of white supremacy (Smith et al., 2002) and perpetuates white norms in organizations and institutions. Further, the space with the most White people, and perhaps the most un-interrogated space, is at the top of the ivory tower. If higher education leaders are to foster the success of a growingly diverse student population and respond to an increasingly diverse and global world, they must concern themselves with social and racial justice and embody reflexivity and criticality.

\section{Methodology}

At the heart of this study was the frequently invisible phenomenon of whiteness. 
Journal Committed to Social Change on Race and Ethnicity | Volume 7, Issue 1 | 2021

In order to illuminate the phenomenon of whiteness in higher education, we combined a phenomenological approach with critical qualitative inquiry. Cannella and Lincoln (2012) define critical qualitative inquiry as "any research that recognizes power-that seeks in its analyses to plumb the archaeology of taken-for-granted perspectives to understand how unjust and oppressive social conditions came to be reified as historical 'givens'” ( $p$. 105). And, phenomenology explores the lived experiences of people and sheds light on existential meanings (van Manen, 1997). Creswell (2007) explains that phenomenology seeks to describe the meaning of a concept or phenomenon as it exists in the social world. As is evident in the research, whiteness is normalized (Cabrera, 2012), taken-forgranted, hidden, and perpetuated at the individual, institutional, and societal levels (Ortiz \& Rhoads, 2000). Whiteness exists in myriad ways within the social world, including educational institutions. Thus, phenomenology layered with critical qualitative inquiry was most appropriate for exploring and gaining a deeper understanding of the participants' lived experiences and perspectives, of how White higher education leaders navigate racial equity and inclusion efforts at their institutions and the role their racial identity plays in the process.

\section{Positionality of the Researchers}

Researchers can never disengage from our unique worldviews as we gather and interpret data (Denzin \& Lincoln, 2008), thus, critical reflexivity of the researcher's positionality is crucial (Glesne, 2011). Reflexivity “includes examining one's personal and theoretical commitments to see how they serve as resources for generating particular data, for behaving in particular ways... and for developing particular interpretations" (Glesne, 2011, p. 151). Dustin identifies as a White, gay, Christian, able- 
Journal Committed to Social Change on Race and Ethnicity | Volume 7, Issue 1 | 2021

bodied cisgender man from South Carolina. Brandy is a White, heterosexual, cisgender woman with a working-class background from Georgia. We both grew up with a strong narrative that racism manifested at the individual level, perpetuated by "bad" White people, while institutionally, everyone had an equal opportunity to succeed. This traditional belief in the myth of meritocracy began to shatter for each of us when we entered college, began gathering new knowledge about the inequities in society, and perhaps most importantly, when we began developing real and meaningful cross-racial friendships.

Along our journeys, we each became committed to developing our own critical consciousness (Freire, 1970) and committed to forever growing as anti-racist White educational leaders. For over ten years, Dustin has held an educational leadership position in Student Affairs, and Brandy has held an educational leadership position, as well as a faculty position, in Academic Affairs. As White leaders, we work primarily with other White leaders and administrators, given the consistent disproportional representation of White administrators in higher education (Brown, 2004; Gagliardi et al. 2017). Thus, we know intimately the power that White leaders (including ourselves) hold in maintaining whiteness or dismantling it. While we recognize that we have not "arrived," we are always growing and learning from our mistakes, and we are committed to dismantling racism rather than reifying it.

\section{Participants}

This study involved ten White higher education leaders representing a wide range of institutional types and geographic regions across the United States. For the purpose of this study, we employed criterion sampling (Creswell, 2007) to identify a 
Journal Committed to Social Change on Race and Ethnicity | Volume 7, Issue 1 | 2021

small, specific group to examine the phenomenon of whiteness. Interview participants were selected based on the following criteria: (1) self-identify as White; (2) serve in a leadership position as a Director, Dean, Associate Dean, or above; and (3) engaged in some form of equity work at their institution. We intentionally recruited White leaders that had some form of engagement with equity work because it provided a backdrop for us to ask more probing questions during the interview process. Ultimately, this provided an opportunity to better understand each participant's intentions and motives for engaging in racial equity work while analyzing it through a critical whiteness lens.

Participants were recruited using social media, specifically two Facebook groups: 1) Higher Education Professionals; and 2) Student Affairs Professionals Dismantling White Privilege. From the 19 interest forms submitted, 10 individuals met the sampling criteria and participated in this study. Seven participants identified as female and three identified as male. Each participant reported having between 8-18 years in higher education. Seven had Master's degrees and three had Doctorates. They worked at a variety of institutional-types ranging from large public research institutions to small liberal arts institutions to private Ivy Leagues to community colleges. They were geographically located in regions throughout the United States from the Deep South to New England to the Midwest and to the Pacific Northwest.

\section{Data Collection}

Three rounds of 50-60 minute interviews were conducted with eight participants and two rounds of interviews were conducted with two participants (28 interviews total). The private interviews took place via Zoom—a remote video conferencing service—and were audio recorded and transcribed. A semi-structured interview protocol was utilized 
Journal Committed to Social Change on Race and Ethnicity | Volume 7, Issue 1 | 2021

with the purpose of capturing participants' descriptions and stories in order to interpret the meaning of the phenomenon under study (Kvale \& Brinkmann, 2008) and to offer

more flexibility during the interview process (Brinkmann, 2013). Between each round of interviews, we engaged in memo writing (Glesne, 2011) as an analytical tool to critically reflect on our own whiteness and positionality in relation to our White participants. This reflexive practice allowed us to dive deeper into the phenomenon of whiteness and emerging themes and to avoid the reification and centering of our own whiteness in the research process. At the conclusion of each interview round, audio recordings were transcribed, within 48 hours of the interview. Pseudonyms were assigned to each participant to ensure confidentiality throughout the process.

\section{Data Analysis}

In staying true to the phenomenological analysis process, we utilized Yin's (2016) data analysis framework to analyze and interpret the participant data. Yin (2016) outlined five phases of data analysis: (1) Compiling, (2) Dissembling, (3) Reassembling, (4) Interpreting, and (5) Concluding. This approach was both comprehensive and useful to aid in analysis and to apply Vagle's (2016) whole-parts-whole process as a lens to view data.

We utilized ATLAS.ti, an online computer software program, to compile and sort all notes and transcriptions from the 28 interviews. Second, we disassembled the data into smaller pieces by categorizing it into codes. Coding helped us identify the essential aspects of the data and "begin moving methodically to a slightly higher conceptual level" (Yin, 2016, p. 195). Third, as we reassembled the data, we searched for patterns, relationships, connections, or discrepancies that would move us toward a new 
Journal Committed to Social Change on Race and Ethnicity | Volume 7, Issue 1 | 2021

understanding of the participants' relationship with the phenomenon of whiteness. Along the way, we created a schematic diagram in the form of a concept map to help us make meaning of the data (Yin, 2016). Fourth, we shifted our attention to interpreting, or what Yin (2016) refers to as the pinnacle of data analysis. During this phase, we drew upon Critical Whiteness Studies as an analytical tool (i.e., power, ideology) to contextualize the words of the participants and interpret the data.

\section{Findings}

Four themes emerged from the data analysis process: 1) The Overwhelming Presence of Whiteness; 2) Whiteness as "Professionalism"; 3) Whiteness as Niceness; and 4) Developing White Racial Authenticity. Importantly, the undergirding thread through the findings is power. In this section, we expand upon each of the findings by integrating the relevant literature and discuss specific ways in which power manifests at the interpersonal and institutional levels.

\section{The Overwhelming Presence of Whiteness}

One of the major themes that emerged from this study centered on how whiteness is challenged and/or maintained within higher education institutions. The participants highlighted how deeply embedded whiteness is within institutional culture, specifically as it relates to racial representation and power dynamics. These leaders discussed the overwhelming presence of whiteness in key leadership positions and hiring culture. In particular, Dan, a director at a public research institution in the Midwest, shared:

Out of our six cabinet-level positions, they're all white except for one. The university says we want to hire diverse leaders, but when the Chancellor had an opportunity to hire a new diverse Provost, she didn't. We are told to think about 
Journal Committed to Social Change on Race and Ethnicity | Volume 7, Issue 1 | 2021

diversity when we're hiring, but when you look at the leadership of the school, you don't see a diverse population.

Similarly, Audrey, a dean at a community college in the South, stated that as she has ascended the levels of responsibility at her institution, "the spaces have gotten whiter. The frontline staff are super diverse, but there's less representation at the top." Indeed, institutions are "whiter at the top" and a lack of diverse representation in top leadership positions persists. With $86 \%$ of higher education administrators being White (Bichsel \& McChesney, 2017), staff, faculty, and Students of Color rarely see people who look like them in leadership. As Dan indicates, even when institutions are provided with opportunities to hire diverse candidates for cabinet-level positions, White people are often given the position in the name of good fit (Wade-Golden \& Williams, 2013). This finding confirms the phenomenon of the racially coded and problematic nature of the "good fit" approach to hiring (Liera \& Ching, 2020; Tuitt et al., 2007; White-Lewis, 2020; 2021; Williams, 2013). DiAngelo (2011) refers to this phenomenon as the unspoken racial bonds that reinforce white solidarity by continuing to offer White people higher titles, power, and access to resources.

In cases where diversity exists, frontline staff (i.e., hourly employees such as housekeepers, groundskeepers, physical plant workers) or entry-level employees are more likely to be People of Color than upper-level administrators. Dan speaks to this reality in a way that challenges institutional norms embedded in whiteness and simultaneously reinforces whiteness:

We struggled a couple of years ago when several of our young staff members of Color left because they felt like they were tokens. Now, the reality is they weren't, but they were asked to do lots of things like be on committees and all that kind of stuff. They would start questioning why they were even here, and then we would lose them. 
Journal Committed to Social Change on Race and Ethnicity | Volume 7, Issue 1 | 2021

In a roundabout way, Dan dismisses the experiences of the staff members of Color by stating, "they felt like they were tokens. Now, the reality is they weren't..." Clearly, his assumption is shaped by his whiteness. When he makes this comment, although unintentional, he is reifying his perspective as the ultimate truth, thus delegitimizing the experiences of People of Color that are often, in fact, a result of tokenism (Kelly, 2007). Interestingly, Dan also reinforces his lack of understanding of his own white privilege when he juxtaposes why he remains at his institution while some staff and leaders of Color end up leaving:

I have a lot of friends of Color that come and go from the university. I think to myself, how am I still here? What about my experience is easier than what they had? I think it is because my position is so unique and nobody really knows what I do, or they just don't want to do it. I think this has protected me over the years.

Dan thinks that he is "unique," but he does not own the fact that his whiteness is what protects him from leaving. This perspective is anchored in white racial innocence - the stance that White people take in order to remain blissfully "unaware" of our whiteness so we do not have to interrogate our racial privilege (DiAngelo, 2018).

On the other perspective, Audrey sheds light on an important misperception often experienced in higher education: diverse representation equals racial equity. She shares the following about her community college's campus culture:

Because my campus is so diverse, leaders think we don't have a problem. They say, "we wouldn't be a Hispanic Serving Institution if our Latino students felt like they were being discriminated against. Thirty percent of our employees wouldn't be Black if they were being discriminated against." We assume that representation equals equity or justice. I think there is a perception that we don't have a race or inclusion problem because there are diverse people here.

Audrey draws attention to the commonplace assumption that diversity-the presence of difference-automatically equals inclusion and equity. This reinforces an institutional 
Journal Committed to Social Change on Race and Ethnicity | Volume 7, Issue 1 | 2021

culture that never addresses race, racism, or racial equity head on—one of the hallmark symptoms of whiteness.

From a different angle on representation and institutional culture, several of the participants discussed the utilization of Black and Brown bodies to recruit diverse students to their institutions to satisfy strategic goals and/or internal or external pressures to diversify. The participants seemed to struggle with the misalignment between the institution's actions and their personal values around racial equity. For example, Rebecca, an Associate Dean at a private liberal arts school in the MidAtlantic, captured this phenomenon best:

While working at a predominantly White institution, I oversaw a program primarily for Students of Color. I remember the Communications and Admissions Office created pamphlets and flyers for prospective students. I was looking through the pamphlets and realized they were using our students, having them peppered throughout all of these pamphlets, brochures, and website. That really did not create an accurate picture of what the campus was like, and I think my current institution is guilty of this as well. I thought that was inappropriate, and I felt like it was luring other Students of Color into an environment that they were not necessarily welcomed in and where they wouldn't have a positive experience. It was a tool to draw people in. I get diversity as an institutional goal, and that's not inappropriate at all. In fact, I support that $100 \%$, but I think it's inappropriate to do that by creating a false sense of security and inclusion.

Rebecca's example is a common practice in higher education. In an effort to increase diversification, institutions disproportionately represent People of Color in their marketing materials. Rebecca's statement about institutions "luring Students of Color" onto campus magnifies the notion that Black and Brown students' bodies are commodified for "diversity" in these materials (Pippert et al., 2013). Doing as they have been instructed, marketing departments have endeavored to create images of diversity to help encourage enrollments from Students of Color by communicating a false sense of belonging. For those creating these materials with the best of intentions about power 
Journal Committed to Social Change on Race and Ethnicity | Volume 7, Issue 1 | 2021

and blindspots is relevant here (Kezar \& Posselt, 2020). Further, Rebecca's perspective further highlights her ability to see and name the structural components of whiteness in higher education and how institutions seek to replicate it (Gusa, 2010), yet she remains distant from naming action steps to address these inequities.

\section{Whiteness as "Professionalism"}

Another theme that emerged was the notion of how power dynamics shape white standards of "professionalism" in higher education. As highlighted below, the standards of professionalism such as dress code, speech, work style, and timeliness, are heavily defined by whiteness (Okun, 2010). Amy, a Director and Assistant Dean at a private liberal arts college in the Pacific Northwest, speaks to these dynamics and offers an example of how whiteness gets reinforced through institutional and leadership culture. She states:

There's a sense of detachment and lack of awareness of the power dynamics at play. You can't erase hierarchical differences and identity-based power dynamics. There's also a lack of interrogating how leaders' whiteness reinforces those power dynamics. Things like rushing to make decisions and creating a sense of urgency or need to control a situation. I see that happen within our leadership structures, but it's not talked about in a way that is tied to whiteness.

Amy not only names whiteness in leadership, but she also articulates how whiteness manifests in leaders' actions and behaviors. Many leaders fail to understand that rushing to make decisions, creating a sense of urgency, and attempting to control the narrative are indeed, functions of whiteness that lead to racial inequity and exclusion (Jones \& Okun, 2016). When these power dynamics are left unnamed or unchallenged, they perpetuate white supremacy culture throughout the institution (Ansley, 1997).

Another power dynamic that serves to reinforce white cultural norms and racial inequity in higher education institutions is what another participant, Sue, refers to as 
Journal Committed to Social Change on Race and Ethnicity | Volume 7, Issue 1 | 2021

"our sense of professionalism in the workplace that is grounded in an overbearing sense of whiteness." Sue, an executive director at a public research institution in the Southeast, says the term "professionalism" is a loaded word because it is steeped in whiteness: "Who determines what is professional and what is not?" For example, she points out that during a divisional diversity working group to address a series of topics related to retention, recruitment, satisfaction, recognition, and overall workplace climate, the discussion was about the need to follow university rules and policies. She states:

We had a lot of discussion about hair. Essentially, folks couldn't wear any kind of hat or headdress without a religious connection. During the conversation, there lacked any acknowledgement that upkeep and maintenance of hair is difficult at times in the town we live in, particularly for our staff members of Color who don't have access to salons, so they might have to wear a headscarf. So, they would not meet the policy for "professional" dress. I think "professionalism" in and of itself sits with a lot of privilege.

In addition to professionalism related to dress, these leaders talked about what

Amy called, "other signs and signals of white supremacist culture that you wouldn't necessarily identify but permeates workplaces." Amy discusses racialized expectations and differential reinforcement of standards:

I think that even some of our basic expectations around promptness and thoroughness in communication or follow-through are often inconsistently held on the basis of race. When there is a norm around doing certain things in a timely manner, I often see the way that expectation is not upheld consistently. A person of Color might get a really snarky email from the business office about something being turned in late, and as a White person, I could be late doing the same thing and I get a really polite response or a gentle reminder. It's the same professional expectation, but we're not held to it in the same way.

Similarly, Sue provides concrete examples of how whiteness infiltrates hiring committee processes and decision-making based on perceptions of professionalism as perfection. In this case, candidates of Color were dismissed from further review because of their name, where they went to school, or imperfections in their materials. 
Journal Committed to Social Change on Race and Ethnicity | Volume 7, Issue 1 | 2021

She states, "The 'professional' expectation from the search committee is that folks write perfectly, never have typos, know perfect English, etc. The committee will say, 'I don't see what we're looking for in these materials,' and they don't consider them for the position." This biased mentality replicates assumptions and actions steeped in the perfectionism and other ideals of white supremacy (Ansley, 1997; Jones \& Okun, 2016) and further supports what White-Lewis (2020) refers to as code for determining the palatability of candidates of Color-including language, presentation, and appropriate cultural capital—for predominantly white search committees.

Finally, Liz, a director at a private research institution in the Southeast, expands this discussion of whiteness as professionalism by situating it in the context of white emotionality (Matias, 2016). Liz shares:

As a White person, I can have a thought or opinion and share that passionately, but that isn't me being emotional per se. However, some may consider my colleague of Color's [sic] passionate response to be unprofessional. They're told to calm down or seen as too emotional or unprofessional.

Here, a new theme emerge embedded within the concept of professionalism - the discourse of "whiteness as niceness." When People of Color show emotions other than niceness (as defined by their White peers) they are often seen as disruptive or abrasive. When White people express similar levels of passion or emotionality, we are often affirmed. However, when White people's behaviors or emotions are not affirmed, angst kicks in and respect is demanded, a component of white emotionality (Matias, 2016), that reifies racism and whiteness in institutional culture.

\section{Whiteness as Niceness}

Drawing from the previous theme of whiteness as "professionalism," the third theme highlights the ways in which White leaders reinforce, intentionally or not, a 
Journal Committed to Social Change on Race and Ethnicity | Volume 7, Issue 1 | 2021

"whiteness as niceness" culture. The leaders shared examples of when it was most difficult for them to navigate racial conversations on their campus. John, a director at a public research institution in the Northeast, shares how difficult it is for him to hold other White people accountable for racist actions, especially when power dynamics are at play:

My previous supervisor had a tendency to misname Black staff members by using the wrong name for them on more than one occasion. It wasn't a regular thing, but I think the connotation was sort of, well, "they all look alike"... at least that's how it came across. One time, I was present at a larger training when he did this, and he joked and laughed it off and said something like, "Oh wow, I'm so sorry. I'm getting old." I didn't say anything because I couldn't... I think a lot of that had to do with the dynamics that he was my boss's boss.

When asked why he chose not to speak up, John explains:

I might be perceived as a rebel without a cause. I might be trying to rock the boat. I think in those instances where credibility once existed, perhaps it's now questioned.

Indeed, the discourse of "whiteness as niceness" is alive in John's actions when he chose to remain complicit by not addressing the racist behavior of his White supervisor for regularly misnaming Black staff members. John's desire to maintain professionalism and not be perceived as a "rebel without a cause" demonstrates his desire to avoid conflict by not addressing racist microaggressions. We operationalize and prioritize whiteness under the guise of professionalism and perpetuate these standards throughout higher education. In order to do your job and do it well, everyone is expected to follow "professional" white norms. These norms, then, serve to reinforce the institutional culture that values white standards of success, and values White people, often at the exclusion of People of Color. In many ways, this finding directly supports Patton and Bondi's (2015) study on White male faculty and administrators' desire to be 
Journal Committed to Social Change on Race and Ethnicity | Volume 7, Issue 1 | 2021

perceived as social justice allies, yet when the opportunity arises to speak up and challenge their White peers, these White leaders remain safely insulated in their whiteness. John's positionality as a White male leader within his division provides him the power and social capital to disrupt this racist behavior. Instead, he invoked the "whiteness is niceness" racial frame. It was more important for him to be perceived as a "nice [White] guy" (Patton \& Bondi, 2015) rather than be seen as an anti-racist advocate, or what he calls a "rebel without a cause."

In addition to interpersonal power dynamics, participants illustrated "whiteness as niceness" at the institutional level. All participants indicated that they had to navigate racial dynamics on a regular basis. Most of the time, the topic of race was hidden under the veil of another topic or was only discussed in private settings. In some cases, race was not to be discussed at all because it could become divisive and separate others. Stacey, a director at a private ivy league in the Mid-Atlantic, provided an example of "whiteness as niceness" when she highlighted the Athletic Department's approach to "diversity" at her institution. She stated:

They [Athletics] see themselves as participating in diversity through numbers. However, when we have discussions about understanding difference, it's in direct contrast to what Athletics tries to promote. For them, they want everyone to be the same; they want the students to be a team. Discussions of race shouldn't happen in the locker room because that's going to be divisive, so they promote diversity by basically being colorblind. It has been a challenge thinking about diversity and inclusion and how it might apply to Athletics when their view on what unity means, and creating community, is diametrically opposed to understanding and seeing folks' differences.

In an effort to build unity and teamwork among the student athletes, who represent a higher proportion of Students of Color than the general student body, the department chose to take a race-neutral approach to racial equity and inclusion by having the 
Journal Committed to Social Change on Race and Ethnicity | Volume 7, Issue 1 | 2021

athletes all be "the same." As is represented in the literature on critical whiteness, this colorblind ideology is the presumption or assertion of a race-neutral social context (Bonilla-Silva, 2001).

This race-neutral approach reinforces a "whiteness as niceness" framework because it is grounded in the department's desire to maintain order. Although perhaps an unspoken or "hidden" expectation, it is easier for the department to promote nicety rather than openly talking about race. Like those with decision-making power in Dowd and Bensimon's (2015) study, the leaders of the department exonerated themselves from any responsibility to advance racial equity (Harper \& Patton, 2007). Thus, Whiteness as niceness perpetuates an institutional culture that never addresses race, racism, or racial equity head on - one of the hallmark symptoms of whiteness within higher education.

\section{Developing White Racial Authenticity}

The final finding that emerged from this study was the importance and complexity of developing white racial authenticity. In particular, participants of this study highlighted the importance of relationships, owning their whiteness, and not relying on People of Color-especially those who work in identity-based centers-to "fix" diversity issues in their departments. Similarly, some discussed how they strive to move beyond a mere title of allyship to actively partner with People of Color in the fight for racial equity.

Reflecting on how relationships impact racial equity work, Liz, a director at a private research institution in the Southeast, acknowledges and owns her white fragility (DiAngelo, 2018) and how it influences her ability to develop meaningful relationships with People of Color. She states: "Whiteness affects human relationships and my ability 
Journal Committed to Social Change on Race and Ethnicity | Volume 7, Issue 1 | 2021

to effectively express my emotions, manage conflict, and explore meaningful, healthy, sustained friendships with people of Color." Discussing race often brings a mix of emotions such as shame, guilt, discomfort, and confusion, as we witnessed with all participants in this study. These white emotionalities (Matias, 2016) often work in tandem with white fragility. Instead of suppressing these feelings, it is important to name, understand, and interrogate them if one ever hopes to fully commit to racial equity. Liz expands on this when she states:

It's this balance of being comfortable with your whiteness and having authentic relationships. I think authenticity means that you're not afraid of shying away from the racial dynamic. It's the balance of "everything is about race, but not everything is about race," and relationships are how you start.

Dan also mentions relationships as important building blocks to developing racial authenticity, but problematically, the example he offers reinforces whiteness. He states:

Being someone from multiple privileged identities, it's really just about curiosity. I have to show people that I'm willing to learn about them on an individual basis. When I was brand new in my role, I had a meeting with the President of the Black Student Association. We were prepping her to meet with our University President and a representative from the Board of Trustees. For me, it was helping that student understand that she was going into a room with a bunch of White people. She could call me racist, and I wasn't going to respond in a negative context because I know I'm not a racist. I mean... I'm not out carrying pitchforks or tiki torches and those kinds of things. I think it helped her understand some of the norms in the setting with the University President and how to shape her conversation so that it wouldn't abruptly stop.

Here, Dan's intent is to show that he supports People of Color by seeing them as individual people, not as a collective sum. Dan offers an example of helping a student of Color "understand some of the norms in the setting." By norms, one can assume Dan is referring to white norms. Although unintentional, Dan is advising the President of the Black Student Association to maintain whiteness (i.e., do not be too loud, abrasive, or disrespectful) so that the conversation will not come to an immediate halt with the 
Journal Committed to Social Change on Race and Ethnicity | Volume 7, Issue 1 | 2021

University President. Despite Dan's intention to look out for the student, he actually serves to reify whiteness, which ultimately protects other White people and reinforces white solidarity (DiAngelo, 2018). In addition, Dan fumbles on his own words to try and cover up his own view of racism that implicates him in whiteness. He quickly clarifies that he is not out carrying pitchforks and tiki torches to help separate himself from "those" (i.e., bad) White people.

In addition to developing cross-racial relationships, participants discussed developing racial authenticity through self-teaching and working to decenter their whiteness. For example, Patrick, an associate dean at a private liberal arts college in the Mid-Atlantic, states: "I try to really not have anyone explain it [race] to me because at the end of the day, that's my job. It's not their burden or labor." Patrick engages People of Color in informal discussions and asks how he can support them to be "as close to whole as possible." This is complex-while this approach can lead to racial fatigue for People of Color, it also signifies that a White leader is also not conducting "business as usual" in the midst of racialized pain and trauma. To develop white racial authenticity, White people have to explicitly see and name race, not hide from it (McIntosh, 1988). Patrick believes that White people have to decenter ourselves and refocus on making space for the wholeness of People of Color.

Importantly, when participants were asked how they practice racial authenticity, a third of them described their efforts to decenter themselves as, "It's not about me." For example, Stacey spoke about her success in supporting Students of Color, yet when racial tensions arose, she would "take it so personally." She says,

Finally, I realized that it was not about me. They [Students of Color] haven't been able to trust people in authority their whole lives, and so they're just waiting for 
Journal Committed to Social Change on Race and Ethnicity | Volume 7, Issue 1 | 2021

me to do the same thing [that another White person did to them previously].

In a similar yet different vein, Sue shared a personal example of when she took up space from Women of Color in her organization:

I've been a member of a sorority for several years. There are Women of Color in my chapter that are just now starting to work with me, and I know it's because I'm White. There are some women who think this is their space, and I'm in their space. I think about that a lot as well, but I do take space away from Women of Color. I have tried to tell myself that it takes time, and if someone doesn't want to work with me or trust me, it's not about me. I'm not going to stress about it. It's about other White people who have ruined People's of Color perceptions of White people and rightly so.

Although Sue uses the same language as Audrey - "it's not about me" - it appears that she tries to distance herself from other White people. In essence, Sue perpetuates the good/bad binary that often prevents White people from engaging more deeply in understanding our role in racial equity efforts (DiAngelo, 2018).

Furthermore, some participants acknowledged the importance of recognizing their privilege in day-to-day interactions and not relying on people of Color to "fix" racial equity issues. For example, Lynn, a dean of a private liberal arts college in the Midwest, discussed how she can often take a more idealistic approach to racial equity and inclusion work, as compared to her colleagues of Color. As a White woman, she feels safe in challenging her White peers and is able to push harder on racial topics. She owns the fact that, at times, she has to put her white ego aside and listen to what her colleagues of Color are saying about their lived experiences:

I have to remember that although I want things to move quickly when I'm on committees, I have to listen to my colleagues of Color. I'm currently on our diversity and inclusion framework committee. We've discussed taking out the term racism from the framework, but l've been someone who has been adamant that the word needs to be in there. I've been able to be adamant as a White person, whereas some of my colleagues of Color are a little bit more hesitant and pragmatic. I've been able to be more idealistic because I'm a White woman who 
Journal Committed to Social Change on Race and Ethnicity | Volume 7, Issue 1 | 2021

has never experienced all the microaggressions my colleagues of Color have experienced when they use the word racism. Those are times when l've got to put my own white ego aside, which feels like taking half measures, but it's not about me.

While Audrey, Sue, and Lynn all use the phrase, "it's not about me" to describe their efforts to decenter their whiteness, they each take a different approach to do so. Importantly, each approach is embedded with a certain invisible power dynamic or blindspot (Kezar \& Posselt, 2020), which results in the participants both disrupting and reifying their whiteness.

\section{Discussion and Implications for Anti-Racist Leadership}

This study builds on the existing research of race, racism, and white supremacy in higher education by offering insight into how whiteness manifests at the institutional and personal levels, particularly with White leaders. As Patton (2016) argues, higher education must explicitly name racism and white supremacy, including "foregrounding race, disrupting dominant, Eurocentric ideologies, challenging neutrality and colorblindness, and legitimizing the experiences of people of color" (p. 335). The participants in this study presented several instances when their whiteness was a barrier to engagement and leadership. One of this study's participants summed this up well when she shared:

The system is working exactly how it was designed to work. None of this is by chance or happen-stance. We didn't just accidentally stumble into white supremacy. We got here very intentionally, and our systems that are inequitable are working as designed. So, we have to acknowledge the intentionality behind it, then dismantle and disrupt it.

Indeed, we must recognize the inherent white supremacist system in which we find ourselves today while also developing intentional strategies to dismantle and disrupt it. To follow, we offer five recommendations for White higher education leaders to develop 
Journal Committed to Social Change on Race and Ethnicity | Volume 7, Issue 1 | 2021

anti-racist leadership practices and begin thinking differently about our work in relation to our whiteness.

Examine racial biases, assumptions, and power dynamics. Good leadership means becoming more aware of our own biases, which affect the relationships we build with People of Color and how we create and interpret institutional policies and procedures. White leaders have to continuously practice awareness of how our white racial identities maintain white norms and power dynamics that reify institutional racism and whiteness (Kezar \& Posselt, 2020). For example, as leaders and as White people, we have the power to determine what is valuable, acceptable, professional, scholarly, and quality. On a daily basis, we are posed with questions and decisions that impact the lives and experiences of students, staff, and faculty. We have the power to say "yes" or "no" to the ideas of People of Color and to equity-based programs. We have the power to nurture others' success, or create barriers and roadblocks. Additionally, we have the power to sustain and perpetuate institutional racism and discredit the realities of People of Color, or we have the power to show up as inquiry-based scholarly leaders seeking to better understand and act in dismantling racist structures. Bensimon originated the term equity-mindedness to describe this kind of thoughtful leader we describe here-a leader who is conscious of race; aware of racialized patterns embedded in the university's practices, polices, and cultures; and takes responsibility for eliminating racial inequity by changing practices, policies, and cultures (Dowd \& Bensimon, 2015).

Address representation and the overwhelming presence of whiteness. As much of the existing literature lays out, diversification and representation (particularly in leadership and decision-making roles) are crucial for shifting institutional culture and 
Journal Committed to Social Change on Race and Ethnicity | Volume 7, Issue 1 | 2021

norms. White-Lewis (2020) recommended that institutional leaders provide greater clarity on the importance of identity in all stages of the hiring process rather than a color-convenience perspective where identity is emphasized in position advertisements; neglected in evaluation; and then conveniently invoked to a candidate's of Color detriment when making a final offer. We, along with other scholars, recommend making anti-racism and equity central to an institution's teaching and scholarly mission to avoid fear of legal repercussions (Wade-Golden \& Williams, 2013; Williams, 2013).

Additionally, administrators and faculty must also consider the procedural elements of the hiring process (White-Lewis, 2021). Like White-Lewis (2021), Liera (2020b) concluded that racial equity in hiring can be achieved "by manipulating and subverting practices (e.g., recruitment strategies, evaluation criteria), rules (e.g., conversations about race), and roles (e.g., legitimate roles as committee members who have the knowledge to integrate equity-mindedness) that historically excluded racially minoritized [candidates]" (p. 33). Senior administrators must take an active role to commit to diversification, to train search committee members to take active steps to create an equity-minded evaluation system, to utilize equity templates, and appoint people on search committees who are explicitly trained to advocate for equity in the evaluation process (Liera, 2020b; White-Lewis, 2021).

Interrogate the power dynamics of "professionalism." As the White leaders in this study highlight, assertions of "professionalism" serve to reinforce white cultural norms and power dynamics that benefit White people. These power dynamics manifest through formal structures (i.e. rules, policies, hiring practices) and informal structures (i.e. work style, emails, speech) (Jones \& Okun, 2016). Additionally, power dynamics 
Journal Committed to Social Change on Race and Ethnicity | Volume 7, Issue 1 | 2021

emerge when White leaders create an imaginary sense of urgency in decision-making. Oftentimes, this sense of urgency makes it difficult to take time to be inclusive and to encourage democratic or thoughtful decision-making and makes decision-making more clear to those with power (i.e., White people) and unclear to those without it (i.e., People of Color) (Okun, 2010). Using a critical whiteness lens, White anti-racist leaders must disrupt the notion and intricacies of "professionalism" and begin to interrogate and challenge the power dynamics that often serve to reinforce white norms and expectations by critically asking "why?" and "who benefits from this decision?" This involves assessing, rewriting, and in some cases, overhauling policies and practices that were designed to protect whiteness. Topics around professional attire, hairstyle, language, and style of expression, should be part of the discourse, so institutions can begin to untangle what it means to be "professional" in higher education (Bader \& Salinas, 2017; Bader et al., 2016). Furthermore, when White leaders are tasked with decision-making, we must take stock of how decisions are made and aim to disrupt the status quo.

\section{Notice "whiteness as niceness" and act courageously against this norm.}

White leaders can no longer tiptoe around race. When we do this, we invoke the "whiteness as niceness" racial frame and seek to maintain our own racial comfort. Ray and Purifoy (2019) assert that this culture of niceness is rooted in colorblind ideology and is repackaged as professionalism, collegiality, and teamwork. In order to disrupt "whiteness as niceness "culture, White anti-racist leaders must hold ourselves and other White leaders responsible for our actions and create opportunities for dialogue and personal development. For example, we must notice when we are engaging in circular 
Journal Committed to Social Change on Race and Ethnicity | Volume 7, Issue 1 | 2021

talk with other White people about race. Oftentimes, we bring together a group of wellintended people from across campus or departments and set lofty, intangible goals around equity and inclusion efforts. White people typically leave these meetings feeling good about ourselves, but there is no personal acknowledgement or ownership of having to give something up. Calling-in our White peers creates a level of personal accountability and helps alleviate the burden carried by people of Color. White antiracist leaders should seek opportunities to integrate racial equity practices into our daily work. This could take many forms such as on-going professional development workshops and trainings focused specifically on racial equity and inclusion, white caucus groups, article discussions during staff meetings, and disaggregating institutional assessment data to better understand the lived experiences of people of Color on our campuses. Perhaps most importantly, White anti-racist leaders should role model positive behaviors and attitudes that publicly confront dominant views and interests of white supremacy. In seeing White leaders challenge the racial status quo, White faculty, staff, and students may begin normalizing these behaviors in their own daily practice.

\section{Develop authenticity in everyday interactions and relationships.}

Relationships help build bridges and connections across racial differences. These authentic relationships are at the core of racial equity work and help sustain movements across generations. With the overwhelming presence of White people in higher education leadership positions (Bichsel \& McChesney, 2017), it is often more convenient for White people to turn to their White peers and ask their opinions about diversity, equity, and inclusion at their institutions. This action reinforces white solidarity 
Journal Committed to Social Change on Race and Ethnicity | Volume 7, Issue 1 | 2021

(DiAngelo, 2018), and is counter to anti-racist leadership. Rather, White leaders have to be in real, authentic relationships with People of Color, and be prepared to listen and take action. To do this, White anti-racist leaders need to have a strong understanding of how whiteness and racism are structured at their institution and within society. This allows us to better understand and connect with another person's experience while remaining committed to dismantling institutional racism. Furthermore, this work involves proactively working alongside our colleagues of Color and other White anti-racist leaders to build coalitions to critically examine climate and culture, as well as policies, programs, and practices that reinforce whiteness within our institutions. In group settings, this means sharing airtime and intentionally structuring meetings to ensure that everyone in the room, not just White people, have opportunities to share their thoughts and ideas and making sure those thoughts and ideas are heard and taken seriously. Finally, and importantly, white anti-racist leaders must take ownership for when (not if) we make mistakes. This process takes humility, authenticity, and a deep awareness from the White leader of how they are positioned within relationships, their institution, and society.

\section{Conclusion}

Indeed, higher education needs bold, courageous anti-racist leaders who have the vision, commitment, and skills to transform our institutions into equity-minded places of learning. This critical phenomenological study explored how White higher education leaders navigate racial equity and inclusion efforts at their institutions and the role their racial identity plays in the process. As demonstrated in the findings of this study, White higher education leaders navigate equity and inclusion efforts in myriad ways by their 
Journal Committed to Social Change on Race and Ethnicity | Volume 7, Issue 1 | 2021

action or inaction toward challenging institutional culture and standards of professionalism. Furthermore, this study highlights the complexities and intricacies of how White leaders develop white racial authenticity in order to sustain racial equity and inclusion efforts on their campuses. Finally, in recognizing the importance of theory to praxis, we offer five recommendations that White higher education leaders can employ to develop anti-racist leadership practices and transform our institutions 
Journal Committed to Social Change on Race and Ethnicity | Volume 7, Issue 1 | 2021

\section{References}

Ahmed, S. (2005). The language of diversity. Ethnic and Racial Studies, 30(2), 235256.

Ansley, F. L. (1997). White supremacy (and what we should do about it). In: R. Delgado, \& J. Stefancic (Eds.), Critical white studies: Looking behind the mirror. (pp. 592595). Temple University Press.

Bader, D. \& Salinas, C. (2017). Professionalism in higher education. In T. Geraint (Ed.), Professionalism: Perspectives and practices of the 21st century, (pp. 101-122). Nova Science Publishers, Inc.

Bader, D., Salinas, C., \& Maslin-Ostrowski, P. (2016). Using the wisdom development theory to conceptualize student professionalism development in community colleges. Community College Journal of Research and Practice, 41(4-5), 329332. DOI:10.1080/10668926.2016.1251356

Bichsel, J., \& McChesney, J. (2017, March). Pay and representation of racial/ethnic minorities in higher education administrative positions: The century so far. Retrieved from https://www.cupahr.org/surveys/research-briefs/2017-pay-andrepresentation-of-ethnic-minorities-in-higher-education-administrative-positions/

Bonilla-Silva, E. (2001). White supremacy \& racism in the post-civil rights era. Lynne Rienner Publishers.

Bonilla-Silva, E. (2006). Racism without racists: Color-blind racism and the persistence of racial inequality in the United States (2nd ed.). Rowman \& Littlefield.

Brinkmann, S. (2013). Qualitative interviewing: Understanding qualitative research. Oxford University Press.

Brown, K. M. (2004). Leadership for social justice and equity: Weaving a transformative framework and pedagogy. Educational Administration Quarterly, 40(1), 77-108.

Bryson, B. S. (2017). "They were constantly on the losing side of things": The Pedagogical Power of an African American Teacher Candidate Bearing Witness in Teacher Education. Race, Ethnicity and Education, 20(4), 527-545.

Bryson, B.S., Masland, L. \& Colby, S. (2020). Strategic faculty development: Fostering buy-in for inclusive excellence in teaching. The Journal of Faculty Development, 34(3), 107-116.

Cabrera, N. L. (2009). Invisible racism: Male, hegemonic whiteness in higher education (Unpublished doctoral dissertation). University of California, Los Angeles.

Cabrera, N. L. (2012). Working through whiteness: White male college students challenging racism. The Review of Higher Education, 35(3), 375-401.

Cabrera, N.L., (2017). White immunity: Working through some of the pedagogical pitfalls of "privilege." Journal Committed to Social Change on Race and Ethnicity, 3(1), 78-90.

Cannella, G. S., \& Lincoln, Y. S. (2012). Deploying qualitative methods for critical social purposes. In S. R. Steinberg \& G. S. Cannella (Eds.), Critical qualitative research reader (pp.104-114). Peter Lang.

Chesler, M., Lewis, A., \& Crowfoot, J. (2005). Challenging racism in higher education: Promoting justice. Lanham, MD: Rowman \& Littlefield Publishers, Inc.

Creswell, J. W. (2007). Qualitative inquiry and research design: Choosing among five approaches (2nd ed.). Thousand Oaks, CA: Sage. 
Journal Committed to Social Change on Race and Ethnicity | Volume 7, Issue 1 | 2021

Dancy, T. E., Edwards, K. T., \& Earl Davis, J. (2018). Historically white universities and plantation politics: Anti-Blackness and higher education in the Black Lives Matter era. Urban Education, 53(2), 176-195.

Delgado, R., \& Stefancic, J. (2001). Critical race theory: An introduction. New York University Press.

Denzin, N., \& Lincoln, Y. (Eds.). (2008). Collecting and interpreting qualitative materials (3rd. ed.). Sage.

DiAngelo, R. (2011). White fragility. International Journal of Critical Pedagogy, 3(3), 5470.

DiAngelo, R. (2018). White fragility: Why it's so hard for white people to talk about racism. Beacon Press.

Dowd, A. C., \& Bensimon, E. M. (2015). Engaging the "race question": Accountability and equity in U.S. higher education. Teachers College Press.

Feagin, J., Vera, H., \& Imani, N. (1996). The agony of education: Black students at white colleges and universities. Routledge.

Frankenberg, R. (1993). White women, race matters: The social construction of whiteness. University of Minnesota Press.

Freire, P. (1970). Pedagogy of the oppressed. Continuum.

Gagliardi, J., Espinosa L., Turk, J., \& Taylor, M. (2017). American college president study 2017. American Council on Education. https://www.aceacps.org/

Glesne, C. (2011). Becoming qualitative researchers (4th ed.). Pearson.

Gusa, D. L. (2010). White institutional presence: The impact of whiteness on campus climate. Harvard Educational Review, 80, 464-490.

Harper, S. R. (2020). Racial breakthroughs: Born of student protest. American Federation of Teachers. Retrieved from https://www.aft.org/ae/fall2020/harper.

Harper, S. R., \& Hurtado, S. (2007). Nine themes in campus racial climates and implications for institutional transformation. In S. R. Harper \& L. D. Patton (Eds.), New Directions for student Services: Responding to the realities of race on campus, 120, (pp. 7-24).

Harper, S. R., \& Patton, L. D. (Eds.). (2007). New Directions for student Services: Responding to the realities of race on campus, 120. Jossey-Bass.

Hurtado, S., Alvarez, C. L., Guillermo-Wann, C., Cuellar, M., \& Arellano, L. (2012). A model for diverse learning environments: The scholarship on creating and assessing conditions for student success. In J. C. Smart \& M. B. Paulsen (Eds.), Higher education: Handbook of theory and research, 27, (pp. 41-122). Springer.

Jones, K. \& Okun, T. (2016). Dismantling Racism Workbook. www.dismantlingracism.org

Kelly, H. (2007). Racial tokenism in the school workplace: An exploratory study of black teachers in overwhelmingly white schools. Educational Studies, 41(3), 230-254.

Kezar, A., \& Posselt, J. (Eds.). (2020). Higher education administration for social justice and equity: Critical perspectives for leadership. Routledge.

Kvale, S., \& Brinkmann, S. (2008). Interviews: Learning the craft of qualitative research interviewing. (2nd ed.). Sage.

Leonardo, Z. (2004). The color of supremacy: Beyond the discourse of 'white privilege'. Educational Philosophy and Theory, 36(2), 137-152. doi:10.1111/j.1469-

5812.2004.00057.x 
Journal Committed to Social Change on Race and Ethnicity | Volume 7, Issue 1 | 2021

Liera, R. (2020a). Moving beyond a culture of niceness in faculty hiring to advance racial equity. American Educational Research Journal, 57(5), 1954-1994. https://doi.org/10.3102/0002831219888624

Liera, R. (2020b). Equity advocates using equity-mindedness to interrupt faculty hiring's racial structure. Teachers College Record, 122(9), 1-42.

Liera, R., \& Ching, C. (2020). Reconceptualizing "merit" and "fit": An equity-minded approach to hiring. In A. Kezar \& J. Posselt (Eds.), Administration for social justice and equity in higher education: Critical perspectives for leadership and decision-making. Routledge.

Matias, C. E. (2016). Feeling white: Whiteness, emotionality, and education. Sense Publishers.

Matias, C. E. \& Grosland, T. J. (2016). Digital storytelling as racial justice: Digital hopes for deconstructing whiteness in teacher education. Journal of Teacher Education, 67(2), 152-164. DOI: $10.1177 / 0022487115624493$

Matias, C. E. (2015). "I ain't your doc student": The overwhelming presence of whiteness and pain at the academic neoplantation. In K. Fasching-Varner, K. A. Albert, R. W. Mitchell \& C. Allen (Eds.), Racial battle fatigue in higher education: Exposing the myth of post-racial America (pp. 59-68). Rowman \& Littlefield.

Mclntosh, P. (1988). White privilege and male privilege: A personal account of coming to see correspondences through work in women's studies. Wellesley College, Center for Research on Women.

Milem, J. F., Chang, M. J., \& Antonio, A. L. (2005). Making diversity work on campus: A research-based perspective. Washington DC: Association of American Colleges and Universities.

Okun, T. (2010). The emperor has no clothes: Teaching about race and racism to people who don't want to know. Information Age Publishing, Inc.

Ortiz, A. \& Rhoads, R. (2000). Deconstructing whiteness as part of a multicultural educational framework: From theory to practice. Journal of College student Development, 41(1), 81-93.

Patton, L. D. (2016). Disrupting postsecondary prose: Toward a critical race theory of higher education. Urban Education, 51(3), 315-342. DOI: $10.1177 / 0042085915602542$

Patton, L. D., \& Bondi, S. (2015). Nice white men or social justice allies?: Using critical race theory to examine how white male faculty and administrators engage in ally work. Race Ethnicity and Education, 18(4), 488-514. doi:10.1080/13613324.2014.1000289

Patton, L. D., Harper, S. R., \& Harris, J. C. (2015). Using critical race theory to (re)interpret widely-studied topics in U.S. higher education. In A. M. MartinezAleman, E. M. Bensimon, \& B. Pusser (Eds.), Critical approaches to the study of higher education (pp. 193-219). Johns Hopkins University Press.

Pippert, T. D., Essenburg, L.J, \& Matchett, E.J. (2013) We've got minorities, yes we do: Visual representations of racial and ethnic diversity in college recruitment materials. Journal of Marketing for Higher Education, 23(2), 258-282.

Ray, V., \& Purifoy, D. (2019). The colorblind organization. In Wooten, M. E. (Ed.), Race, organizations, and the organizing process (pp. 131-150). Emerald Group. 
Journal Committed to Social Change on Race and Ethnicity | Volume 7, Issue 1 | 2021

Salinas Jr., C. \& Lozano, A. (2019). Mapping and recontextualizing the evolution of the term latinx: An environmental scanning in higher education, Journal of Latinos and Education, 18(4), 302-315. DOI: 10.1080/15348431.2017.1390464

Smith, W., Altbach, P., \& Lomotey, K. (Eds.). (2002). The racial crisis in American higher education: Continuing challenges for the twenty-first century. State University of New York Press.

Squire, D., Williams, B., \& Tuitt, F. (2018). Plantation politics and neoliberal racism in higher education: A framework for reconstructing anti-racist institutions. Teachers College Record, 120(14), 1-20.

Stewart, D. L. (2018). Minding the gap between diversity and institutional transformation: Eight proposals for enacting institutional change: Facilitating institutional change for racial equity in the educational pipeline. Teachers College Record, 120(14), 1-16.

Tuitt, F. A., Danowitz Sagaria, M. A., \& Turner, C. S. V. (2007). Signals and strategies in hiring faculty of color. In J. C. Smart (Ed.), Higher education: Handbook of Theory and Research Volume xxii (pp. 497-535). Springer.

Vagle, M. D. (2016). Crafting phenomenological research. Routledge.

van Manen, M. (1997). Researching lived experience: Human science for an action sensitive pedagogy. The Althouse Press.

Wade-Golden, K. \& Williams, D. (2013). The Chief Diversity Officer. Stylus.

Welton, A. D., Owens, D. R., \& Zamani-Gallaher, E. M. (2018). Anti-racist change: A conceptual framework for educational institutions to take systemic action. Teachers College Record, 120(14), 1-22.

White-Lewis, D. K. (2021). Before the ad: How departments generate hiring priorities that support or avert faculty diversity. Teachers College Record, 123(1), 1-36.

White-Lewis, D. K. (2020). The Facade of Fit in Faculty Search Processes. Journal of Higher Education, 91(6), 833-857. https://doi.org/10.1080/00221546.2020.1775058

Williams, D. A. (2013). Strategic diversity leadership: Activating change and transformation in higher education. Stylus.

Yin, R. K. (2016). Qualitative research from start to finish (2nd ed.). The Guilford Press. 